DOI: 10.34015/2523-4552.2020.2.07

УДК 35.08 (477)

Кравчук О. Л.,

оперуповноважений ВКП

Шевченківського ВП ГУНП

у Львівській області

ORCID: 0000-0002-6189-5931

\title{
ПРОТИПРАВНІСТЬ ЯК ОЗНАКА ПОРУШЕННЯ ПРИСЯГИ
}

У статті досліджено протиправність як ознаку порушення присяги. Наголошено, що якщо дотримання службово-трудової дисципліни досягається методами заохочення, переконання, виховання, а за потреби - методами примусу, які полягають у застосуванні до її порушників заходів дисциплінарного і громадського впливу, то забезпечити дотримання присяги можна тільки негативним і суворим методом - звільнення зі служби, без права обіймати в майбутньому визначені категорії посад. Зазначено, що завдання державної служби, які корелюються зі змістом Присяги державного службовця, полягають насамперед у належному забезпеченні державно-управлінських відносин, яким властивий свідомо вольовий характер. Зміст Присяги державного службовця, який закріплює обов'язок службовця вірно служити Українському народові, тим самим вказує на загальний обов'язок органів державної служби, місцевого самоврядування та інших органів державної влади служити народу, як прояв публічного адміністрування.

Ключові слова: права людини; право на пращю; службова дисципліна; присяга; державна служба; протиправність; правопорушення.

В статье исследована противоправность как признак нарушения присяги. Отмечено, что если соблюдение служебно-трудовой дисциплины достигается методами поощрения, убеждения, воспитания, а при необходимости - методами принуждения, заключающиеся в применении к ее нарушителям мер дисциплинарного и общественного воздействия, то обеспечить соблюдение присяги можно только отрицательным и строгим методом освобождение из службы, без права занимать в будущем определенные категории должностей. Отмечено, что задача государственной службы, коррелируются с содержанием Присяги государственного служащего, заключаются прежде всего в надлежащем обеспечении государственноуправленческих отношений, которым присущ сознательно волевой характер. Содержание Присяги государственного служащего, который закрепляет обязанность служащего верно служить украинскому народу, тем самым указывает на общий обязанность органов государственной службы, местного самоуправления и других органов государственной власти служить народу, как проявление публичного администрирования.

Ключевые слова: права человека; право на труд; служебная дисциплина; присяга; государственная служба; противоправность; правонарушение. 
Постановка проблеми. Конституція України закріпила за кожним громадянином широкі демократичні права, зокрема право на працю. Однак правове становище громадян визначається не лише їхніми правами, а й обов'язками. Попри право на працю, громадяни зобов'язані сумлінно працювати, додержуватися дисципліни праці, а деякі - дотримуватися складеної перед вступом на посаду присяги. Якщо дотримання службово-трудової дисципліни досягається методами заохочення, переконання, виховання, а за потреби методами примусу, які полягають у застосуванні до ï порушників заходів дисциплінарного і громадського впливу, то забезпечити дотримання присяги можна тільки негативним і суровим методом - звільнення зі служби, без права обіймати в майбутньому визначені категорії посад.

Заразом нормативна регламентація відповідальності службовців за порушення присяги має особливості, властиві лише цьому проступку: невизначеність та неконкретність (абстрактність) кваліфікуючих ознак порушення присяги, як дисциплінарного проступку; відсутність визначеного юридичного складу цього дисциплінарного проступку, що важливо для настання певних юридичних наслідків; найсуворіша відповідальність - звільнення та заборона обіймати окремі посади тощо.

Постановка завдання. Вказане і зумовило вибір теми цієї статті, їі актуальність, теоретичне та практичне значення, а також визначило ії головне завдання - розробити науково обгрунтовані заходи, спрямовані на удосконалення чинного законодавства про державну службу та інших нормативно-правових актів, які передбачають відповідальність за порушення присяги в Україні.

Аналіз останніх досліджень i публікацій. Питання присяги та відповідальності за її порушення в чинному законодавстві вивчають, зокрема, такі науковці: В. Андрєєв, О. Бандура, Н. Бережкова, Ф. Васильєв, С. Данилів, О.Єфімов, О. Кравчук, М. Маськовіта, В. Орленко, В. Пахомова, С. Прилуцький, С. Прилипко, Н. Русакова, О. Скакун, М. Цуркан. Водночас у контексті вибраної тематики наявні праці мають малодосліджений характер. I це додаткова підстава для постановки цього питання саме в такій площині.

Виклад основного матеріалу. Порушення присяги - особливий вид діяння. Про це свідчить навіть те, що до прийняття 10 грудня 2015 р. нового Закону України (далі - ЗУ) «Про державну службу» № 889-VIII [1] (набув чинності з 1 травня 2016 р.) законодавство не давало однозначної відповіді на питання, чи є порушення присяги дисциплінарним проступком, чи це взагалі окремий вид правопорушення, за вчинення якого настає спеціальна відповідальність. Про особливість цього діяння свідчить і те, що до основних конституційних змін, які відбулися в червні 2016 р., відповідальність суддів, прокурорів, як підстава відповідальності за порушення ними присяги, перестала існувати, а для державних службовців (чіткий перелік посад наведено в ЗУ «Про державну службу») встановлена.

Постає запитання: а чи всі працівники рівні перед законом? Адже для одних посадовців передбачено тільки те, що в разі відмови від складання присяги вони не будуть призначені на посаду, для інших - ті ж 
умови, але додається юридична відповідальність за недотримання і порушення присяги, що в подальшому призводить до тяжких наслідків. Тобто є визначена законом категорія осіб, яка зобов'язана при вступі на службу присягнути Україні та/чи народові України на вірність, проте одних посадовців можуть притягнути до відповідальності за порушення присяги, а інших - ні. Відповідно присяга для одних - це юридичний обов'язок зі серйозним механізмом притягнення до відповідальності, який гарантуватиме дотримання та виконання обов'язків, передбачених текстом присяги, а для інших - символічне явище, яке не має юридичної сили для свого захисту (у разі їі порушення), тобто, по суті, зводиться до обов'язку раз присягнути - озвучити не задумуючись, а в майбутньому - можна й не згадувати про існування присяги.

Завдання державної служби, які корелюються зі змістом Присяги державного службовця, полягають насамперед у належному забезпеченні державно-управлінських відносин, яким властивий свідомо вольовий характер. Зміст Присяги державного службовця, який закріплює обов'язок службовця вірно служити Українському народові, тим самим вказує на загальний обов'язок органів державної служби, місцевого самоврядування та інших органів державної влади служити народу, як прояв публічного адміністрування [2, с. 169].

Закон «Про державну службу» № 889-VIII зараховує «порушення присяги» до видів дисциплінарних проступків, що є підставою дисциплінарної відповідальності. Та навіть це не розв'язує тих проблем, які існу- вали до того часу навколо цього специфічного діяння. Ідеться про закріплені цим Законом ознаки, за наявності яких діяння, реально вчинене державним службовцем, визнається дисциплінарним проступком, та ознаки, що відрізняють його від інших дисциплінарних проступків, подібних за юридичною природою, $з$ огляду на нормативне закріплення тексту присяги держслужбовця (ст. 36), поняття службової дисципліни (п. 10, ч. 1 ст. 2) та законодавче визначення дисциплінарного проступку (ст. 65).

У зв'язку із цим є сенс не лише встановити перелік дисциплінарних проступків і передбачити, які дисциплінарні стягнення мають застосовуватися за їх вчинення, а й визначити ознаки, за якими те чи інше діяння державного службовця можна кваліфікувати як конкретний проступок, що може призвести до різних правових наслідків. Тому дослідження підходів до цього процесу дасть змогу уникнути безпідставного зарахування того чи іншого діяння до «порушення присяги».

I. П. Лаврінчук вважає, що загалом правове регулювання припинення трудових правовідносин на державній службі значною мірою зумовлюється характером праці державних службовців, порядком зайняття конкретної посади [3, с. 15]. Тимчасом як порушення присяги було підставою відповідальності для суддів, суддя Вищого спеціалізованого суду України 3 розгляду цивільних та кримінальних справ А. В. Маляренко відзначав, що відповідальність за порушення присяги судді варто передбачити лише за ідеального поєднання зі злочином. Звільнення з посади за порушення присяги як самостійну підста- 
ву треба вилучити з Конституції та законів України. Відтак потрібно об'єднати підстави відповідальності суддів, передбачені в законодавстві, систематизувати їх та конкретизувати $[4$, с. 26].

Частково цю позитивну думку перейняв законодавець: у новому ЗУ «Про державну службу» № 889VIII об'єднав підстави та санкції дисциплінарної відповідальності державних службовців, які до того були закріплені в нормативно-правових актах різної юридичної сили (законі, Кодексі законів про працю, дисциплінарних статутах), тим самим визначивши місце юридичної відповідальності за порушення присяги в галузі дисциплінарної відповідальності; не вилучив порушення присяги з переліку підстав дисциплінарної відповідальності. До того часу порушення присяги та конкретні порушення трудової дисципліни були в різних площинах діяльності державного службовця. За змістом припинення державної служби на підставі п. 6 ч. 1 ст. 30 ЗУ «Про державну службу» № 3723-XII було аналогічним припиненню трудового договору за п. 2 ч. 1 ст. 40 Кодексу законів про працю України (невідповідність займаній посаді) та п. 3 ч. 1 ст. 41 цього Кодексу (вчинення аморального проступку), що, згідно з Постановою Пленуму Верховного Суду України «Про практику розгляду судами трудових спорів» від 6 листопада 1992 р. № 9, не вважалося дисциплінарним стягненням [5].

У новому Законі «Про державну службу» від 10 грудня 2015 р. (ст. 2) поняття присяги розкривається через визначення поняття службової дисципліни - як неухильного додержання присяги державного службов- ця, сумлінного виконання службових обов'язків та правил внутрішнього службового розпорядку; а поняття порушення - через його визначення в п. 1 ч. 2 ст. 65 Закону як одного 3 дисциплінарних проступків.

Важливість встановлення об'єктивного аспекту порушення присяги державними службовцями випливає також 3 аналізу судової практики, адже за відсутності конкретно визначених діянь, що становитимуть порушення присяги, судам доводиться самостійно робити висновки щодо розуміння цієї категоpiï. У цьому контексті варта уваги ухвала Вищого адміністративного суду України від 18 січня 2007 р. у справі № К-29167/06, де вказано, що суть порушення присяги пов'язана 3 такими істотними проступками (вчинками) службовця, які повністю суперечать покладеним на нього обов'язкам, підривають довіру до нього як носія влади та унеможливлюють подальше виконання ним своїх функцій. Незначні факти порушення, які не впливають істотно на роботу органу, не можуть бути підставою для припинення державної служби за порушення присяги [6].

Зазначимо, що Кодекс законів про працю України встановлює можливість правового регулювання трудових відносин (порушення присяги $\epsilon$ частиною таких відносин, нею обумовлено вступ на державну службу) й іншими нормативно-правовими актами, що не суперечать Конституції України та самому Кодексу [7], проте ці інші нормативно-правові акти повинні мати юридичну силу закону. Адже питання про основи державної служби визначаються тільки законами (п. 12 ч. 1 ст. 92 Конституції України). Конституцій- 
ний Суд України в рішенні від 22 червня 2004 р. у справі про Дисциплінарний статут прокуратури вирішив, що такі міжгалузеві акти мають бути обов'язково встановлені на рівні закону [8].

Отже, порушення присяги, як діяння, за яке настає юридична відповідальність, мало подвійну юридичну природу. Новий ЗУ «Про державну службу» (2015) врегулював це питання 3 огляду на конституційне положення (п. 22 ч. 1 ст. 92 Конституції України [9]), згідно з яким тільки Законами України визначаються: засади цивільно-правової відповідальності; діяння, які є злочинами, адміністративними або дисциплінарними правопорушеннями, та відповідальність за них.

Вказівка на наявність ознаки протиправності для кожного дисциплінарного проступку безпосередньо міститься в ч. 1 ст. 65 ЗУ «Про державну службу». Тож робимо висновок, що ознака протиправності властива i проступку «порушення присяги». Проте протиправність у дисциплінарних проступках проявляється не так, як в інших правопорушеннях (наприклад, у злочинах або адміністративних правопорушеннях). Для дисциплінарних проступків характерна відсутність закріплення в нормативних актах конкретних їхніх юридичних складів і прив'язки до відповідних санкцій. Винятком слугують лише прогул, поява на роботі у стані сп'яніння, скоєння за місцем роботи розкрадання і деяких інших порушень [10]. Тому конструкція «протиправності» в порушенні присяги є складною та оціночною.

Згідно зі ст. 2 ЗУ «Про державну службу» № 889-VIII неухильне дотримання присяги, сумлінне вико- нання службових обов'язків та правил внутрішнього службового розпорядку входять до поняття службової дисципліни. Водночас Закон не визначає порушення службової дисципліни самостійною підставою дисциплінарної відповідальності. Оскільки притягнення до дисциплінарної відповідальності можливе, коли діяння особи має ознаки протиправності та винуватості, то ці ознаки у проступку порушення присяги треба розкрити, зважаючи на її зміст, неухильне дотримання якого, власне, слід розглядати як елемент службової дисципліни.

Протиправність дисциплінарного проступку проявляється через:

1) невиконання або неналежне виконання державним службовцем своїх посадових обов'язків;

2) інших вимог, встановлених цим Законом;

3) вимог, встановлених іншими нормативно-правовими актами.

Тільки ті дії чи бездіяльність державних службовців й ухвалені ними рішення можуть вважатися протиправними, які вчинені всупереч законодавчому змісту присяги (ст. 36 3У «Про державну службу»), а саме: вірному служінню Українському народові; дотримання Конституції та законів України, втілення їх у життя; повазі та охороні прав, свобод і законних інтересів людини і громадянина, честі держави; гідного несення високого звання державного службовця; сумлінного виконання своїх обов'язків. Отже, «порушення присяги» має місце тоді, коли протиправно порушуються інші вимоги, встановлені ст. 36 Закону України «Про державну службу».

Проте вивести формулу протиправності в досліджуваному просту- 
пку за змістом тексту присяги не видається можливим, 3 погляду юридичної визначеності. Також у переліку дисциплінарних проступків містяться діяння, які за своєю правовою природою абсолютно тотожні 3 обов'язками, що випливають з присяги. Йдеться, зокрема, про такі проступки, як вияв неповаги до держави, державних символів України, Українського народу, дії, що шкодять авторитету державної служби. На бажання такі дії можна визнати порушенням присяги. Усі вони дещо «штучно» зараховані до дисциплінарних проступків, оскільки не відповідають юридичній природі дисциплінарних проступків. Окрім того, вчинення будь-яких протиправних діянь (кримінальних, адміністративних правопорушень чи дисциплінарних проступків) шкодить авторитету державної служби, по суті, суперечить дотриманню присяги, тому не зрозуміло, про яку саме протиправність у цих діях йдеться.

Неухильне дотримання норм важливий обов'язок усіх громадян, а особливо посадових осіб державних органів. Гідне поводження з державними символами - запорука високого авторитету держави, показник рівня національної свідомості в країні. Саме тому вияв неповаги до державних символів державними службовцями є однією з дій, що свідчить про порушення присяги, оскільки підвищені вимоги до поведінки державних службовців вимагають від них поваги та дбайливого ставлення до державної символіки, що й буде свідченням відданості державі та народу.

Отже, варто погодитися з думкою О.Є. Луценко, яка, аналізуючи порушення присяги, як підставу припинення трудових правовідносин 3 держслужбовцем, вважає, що слід встановити перелік таких конкретних діянь, які характеризуватимуть об'єктивний аспект порушення присяги державними службовцями: 1) вияв неповаги до державних символів України; 2) невиконання або неналежне виконання в межах посадових обов'язків рішень державних органів та/або органів влади Автономної Республіки Крим, наказів, розпоряджень та доручень керівників, наданих у межах їхніх повноважень; 3) перевищення службових повноважень, якщо воно не містить складу злочину або адміністративного правопорушення; 4) невжиття передбачених законом заходів щодо усунення конфлікту інтересів; 5) порушення обмежень щодо участі державного службовця у виборчому процесі, визначених виборчим законодавством [11, с. 59].

У зв'язку із цим простежується тенденція, коли для притягнення до дисциплінарної відповідальності за той чи інший проступок звертаються до аналогії права, закону, тлумачення термінів. У ст. 8 Цивільного кодексу України зазначено: відповідно до ч. 1 аналогія закону - це якщо цивільні відносини не врегульовані цим Кодексом, іншими актами цивільного законодавства або договором, вони регулюються тими правовими нормами цього Кодексу, інших актів цивільного законодавства, що регулюють подібні за змістом цивільні відносини, а аналогія права; відповідно до ч. 2 - коли неможливо використати аналогію закону для регулювання цивільних відносин, вони регулюються відповідно до загальних засад цивільного законодавства [12]. 
Для притягнення державних службовців до відповідальності внаслідок порушення присяги зазвичай використовують аналогію права. Про це свідчить судова практика. Так, Верховний Суд України в ухвалі від 1 жовтня 2013 р. № 21-259a13 у справі про визнання дій та рішень протиправними, скасування наказу й поновлення на посаді визнав, що «порушення присяги - скоєння державним службовцем проступку (вчинку) проти інтересів служби, який суперечить покладеним на нього обов'язкам, підриває довіру до нього, як до носія влади, що призводить до приниження авторитету державного органу та унеможливлює подальше виконання ним своїх обов'язків. Слід відзначити, що норма права, яка безпосередньо би встановлювала такий склад проступку у вигляді порушення присяги, не існує. Тому суб'єкту, якому доводилось накладати стягнення та перевіряти правомірність такого вчинку, доводилось виходить із загального конституційного принципу законності (ст. 19 Конституції України) та принципів ст. 4 Закону України «Про державну службу» - законності, професіоналізму, патріотизму, доброчесності» [13].
Висновки. Отже, у судових рішеннях не йдеться про те, що порушення присяги повинно бути протиправним, винним й одночасно спрямованим проти охоронюваних прав, інтересів, благ. Вбачається, що достатньо встановити факт суперечності вчинку обов'язкам, покладеним на державного службовця. Малоймовірним видається врахування чинників волі та усвідомлення для встановлення протиправності цього діяння. На наш погляд, дещо поверховим і формальним є встановлення протиправності цього діяння тільки на підставі невідповідності вчинків державного службовця його обов'язкам. 3 іншого боку, суд, перевіряючи правомірність рішення суб'єкта владних повноважень у справі про звільнення зі служби за порушення присяги, не $\epsilon$ тим органом, який має повноваження встановлювати склад проступку. Його завдання відповідно до процесуального закону полягає в перевірці й оцінці рішень суб'єктів владних повноважень та обставин, які стали підставою для винесення оскаржуваного рішення.

\section{Список використаних джерел}

1. Про державну службу: Закон України від 10.12.2015 № 889-VIII. База даних «Законодавство України» / ВР України. URL: https://zakon.rada.gov.ua/laws/show/88919\#Tехt (дата звернення: 07.06.2020).

2. Андрєєв В. О. Присяга державного службовця в механізмі проходження державної служби в Україні: дис. ... канд. наук з держ. управл.: 25.00.03 / Нац. акад. держ. управл. при Президентові України. Київ, 2019. 220 с.

3. Лаврінчук І. П. Правовий статус державного службовця як учасника трудових правовідносин: автореф. дис. ... канд. юрид. наук: 12.00 .05 / Київ. нац. ун-т ім. Т. Шевченка. Київ, 1999. 20 с.

4. Маляренко А. В. Про присягу судді та відповідальність за її порушення. Bicник Верховного Суду України. 2012. № 2. С. 26-30. 
5. Про практику розгляду судами трудових спорів: постанова Пленуму Верховного Суду України № 9 від 06.11.1992. Трудове право Украӥни: зб. нормат.-прав. актів. Вид. 2, виправл. та допов. / упоряд. П. А. Бущенко, І. А. Вєтухова. Харків : Консум, 2002. С. 184-210.

6. Ухвала Вищого адміністративного суду України від 18.01.2007 № К29167/06. Єдиний державний реєстр судових рішень. URL: http://www.reyestr.court.gov.ua (дата звернення: 07.06.2020).

7. Кодекс законів про працю: Закон від 10.12.1971 № 322-VIII. База даних «Законодавство України» / ВР України. URL: https://zakon.rada.gov.ua/laws/show/32208\#Техt (дата звернення: 07.06.2020).

8. Рішення Конституційного Суду України у справі про Дисциплінарний статут прокуратури України від 22.06.2004 № 13-рп/2004. База даних «Законодавство України» / ВР України. URL: https://zakon.rada.gov.ua/laws/show/v013p710-04\#Text (дата звернення: 07.06.2020).

9. Конституція України: Закон від 28.06.1996 № 254к/96-ВР. База даних «Законодавство України» / ВР України. URL: https://zakon.rada.gov.ua/laws/show/ 254\%D0\%BA/96-\%D0\%B2\%D1\%80\#Text (дата звернення: 07.06.2020).

10. Угрюмова Г. О. Загальна характеристика дисциплінарної відповідальності і дисциплінарного проступку за українським трудовим правом. Право України. 2005. № 5. С. 78-81.

11. Луценко О.Є. Порушення присяги як підстава припинення трудових правовідносин з державним службовцем. Науковий вісник Ужгородського національного університету. 2013. Вип. 23, ч. 1, т. 2. С. 59-64.

12. Цивільний кодексу України: Закон від 16.01.2003 № 435-IV· База даних «Законодавство Украӥни» / ВР України. URL: https://zakon.rada.gov.ua/laws/show/43515\#Tеxt (дата звернення: 07.06.2020).

13. Ухвала Верховного Суду України від 01.10.2013 № 21-259a13. Єдиний державний реєстр судових рішень. URL: http://www.reyestr.court.gov.ua (дата звернення: 07.06.2020).

\section{References}

Andrieiev, V. O. (2019). Prysiaha derzhavnoho sluzhbovtsia $v$ mekhanizmi prokhodzhennia derzhavnoi sluzhby $v$ Ukraini. (Dys. ... kand. nauk z derzh. upravl.). Nats. akad. derzh. upravl. pry Prezydentovi Ukrainy. Kyiv [in Ukrainian].

Lavrinchuk, I. P. (1999). Pravovyi status derzhavnoho sluzhbovtsia yak uchasnyka trudovykh pravovidnosyn (Avtoref. dys. ... kand. yuryd. nauk). Kyiv [in Ukrainian].

Maliarenko, A. V. (2012). Pro prysiahu suddi ta vidpovidalnist za yii porushennia. Visnyk Verkhovnoho Sudu Ukrainy, 2, 26-30 [in Ukrainian].

Uhriumova, H. O. (2005). Zahalna kharakterystyka dystsyplinarnoi vidpovidalnosti i dystsyplinarnoho prostupku za ukrainskym trudovym pravom. Pravo Ukrainy, 5, 78-81 [in Ukrainian].

Lutsenko, O. Ye. (2013). Porushennia prysiahy yak pidstava prypynennia trudovykh pravovidnosyn z derzhavnym sluzhbovtsem. Naukovyi visnyk Uzhhorodskoho natsionalnoho universytetu, 23, 1, 2, 59-64 [in Russian]. 
O. Kravchuk, operative officer of the criminal police department of the Shevchenkivskyi police department of the Main Directorate of the National Police in the Lviv region

ORCID: 0000-0002-6189-5931

\section{Wrongfulness as a sign of violation of the oath}

The article examines the wrongfulness as a sign of violation of the oath. It is noted that if observance of labor discipline is achieved by methods of encouragement, persuasion, education, and, if necessary, by methods of coercion, then it is possible to ensure the observance of the oath only by a negative and strict method - dismissal from service, without the right to occupy certain categories of posts in the future.

The author noted that the task of the public service, cartelized with the content of the Oath of a public servant, consists, first of all, in the proper provision of state-managerial relations, which are inherently consciously volitional. The content of the Oath of the civil servant, which reinforces the duty of the servant to faithfully serve to the Ukrainian people, thereby indicates the general duty of public service offices, local self-government and other public authorities to serve the people as a manifestation of public administration.

It is concluded that the court decisions do not state that the violation of the oath should be illegal, guilty and directed against the rights, interests, benefits. Judgments only establish the fact that the act contradicts the duties of a civil servant.

In our opinion, it is somewhat superficial and formal to establish the wrongfulness of this act only on the basis of the inconsistency of the actions of a public servant with his duties. On the other hand, the court, checking the legality of the decision of the subject of power in the case of dismissal from service for violation of the oath, is not the authority that was empowered to establish the composition of the misconduct.

Keywords: human rights; right to work; service discipline; oath; civil service; wrongfulness. 